\title{
Developments in the use of nanocapsules in oncology
}

\author{
V. Yurgel, T. Collares and F. Seixas
}

Grupo de Pesquisa em Oncologia Celular e Molecular, Programa de Pós-Graduação em Biotecnologia, Unidade de Biotecnologia, Centro de Desenvolvimento Tecnológico, Universidade Federal de Pelotas, Campus Universitário, Pelotas, RS, Brasil

\begin{abstract}
The application of nanotechnology to medicine can provide important benefits, especially in oncology, a fact that has resulted in the emergence of a new field called Nanooncology. Nanoparticles can be engineered to incorporate a wide variety of chemotherapeutic or diagnostic agents. A nanocapsule is a vesicular system that exhibits a typical core-shell structure in which active molecules are confined to a reservoir or within a cavity that is surrounded by a polymer membrane or coating. Delivery systems based on nanocapsules are usually transported to a targeted tumor site and then release their contents upon change in environmental conditions. An effective delivery of the therapeutic agent to the tumor site and to the infiltrating tumor cells is difficult to achieve in many cancer treatments. Therefore, new devices are being developed to facilitate intratumoral distribution, to protect the active agent from premature degradation and to allow its sustained and controlled release. This review focuses on recent studies on the use of nanocapsules for cancer therapy and diagnosis.
\end{abstract}

Key words: Nanotechnology; Nanocapsules; Nanocarriers; Cancer

\section{Introduction}

The application of nanotechnology to medicine can provide several benefits, especially in oncology, and this has resulted in the emergence of a new field called Nanooncology (1). Drug-loaded nanoparticles provide a promising solution by selectively targeting tumor cells, thereby preventing damage to healthy cells (2). Nanoparticles can be engineered to incorporate a wide variety of chemotherapeutic or diagnostic agents, creating a flexibility in their design that is not possible with other types of drug delivery systems (3).

Active therapeutic molecules are often degraded or opsonized and removed from the bloodstream by macrophages. Therefore, in order to increase blood circulation time and to enhance the probability of the molecule to extravasate in the tumor, a promising alternative is to protect the active molecule inside nanoparticles (4). Colloidal drug carriers can also be rapidly cleared from the systemic circulation due to their recognition as foreign bodies by Kupffer cells in the liver and macrophages in the spleen. Clearance is enhanced by opsonization and activation of the complement system by plasma proteins (5). The elimination and subsequent loss of effectiveness of colloidal systems is strongly influenced by their size, nature, surface charge, and hydrophilicity.
Modifications of the carrier surface have been used to minimize opsonization and clearance by macrophages (6).

The longevity of circulating drug carriers improves drug delivery to their targets, particularly solid tumors (7). This approach makes use of the anatomical and functional differences between normal and tumor vasculature, with angiogenic blood vessels in tumor tissues containing gaps between adjacent endothelial cells. This characteristic coupled with poor lymphatic drainage characterizes the enhanced permeability and retention (EPR) effect. The EPR effect arises from the fact that nanoparticles can easily extravasate through the defective vasculature system in tumors and subsequently accumulate in the tumor microenvironment in the presence of ineffective lymphatic clearance, allowing passive targeting to the tumor region (2). While passive targeting takes advantage of physicochemical and physiological factors, active targeting depends on the attachment of a homing moiety, such as a monoclonal antibody or a ligand, for drug delivery to pathological sites or to cross biological barriers based on molecular recognition processes (8). Active targeting should be based on specific cell surface receptors that are overexpressed on cancerous cells,

Correspondence: F. Seixas, Grupo de Pesquisa em Oncologia Celular e Molecular, Programa de Pós-Graduação em Biotecnologia, Unidade de Biotecnologia, Centro de Desenvolvimento Tecnológico, Universidade Federal de Pelotas, Campus Universitário, 96010900 Pelotas, RS, Brasil. E-mail: seixas.fk@gmail.com

Received September 24, 2012. Accepted March 12, 2013. First published online May 28, 2013. 
thereby distinguishing the malignant cell from other organ cells.

The success of current cancer therapeutic strategies, such as surgery, radiation therapy and chemotherapy is variable (9). The effectiveness of chemotherapy is limited by poor uptake into cancer cells, enhanced detoxification and efficient elimination of the drugs. Moreover, severe side effects in patients can lead to a reduction of the drug dose or even termination of the therapy. In the absence of new drugs, anticancer therapy can be improved by the targeted delivery of conventional chemotherapeutics. These agents usually have limited solubility, poor distribution among cells, and the inability to cross cellular barriers, thereby limiting their clinical use (10). One of the most relevant processes involved in chemoresistance is the overexpression of P-glycoprotein (P-gp). P-gp can transport lipophilic and cationic substrates, and prevent the accumulation of anticancer drugs in cells by pumping out drug molecules from the cytosol. The uptake of drugloaded nanocarriers by cancer cells has the potential to overcome these chemoresistant processes (11).

Nanoparticle-based therapy offers important advantages over the traditional approaches, allowing targeted delivery of high payloads of multiple drugs, controlled drug release, and bypassing multidrug-resistance mechanisms (12). Nanocapsules (NC) are potential nanocarriers for several strategies in oncology. An NC is a vesicular system that exhibits a typical core-shell structure in which active molecules are confined to a reservoir or cavity that is surrounded by a polymer membrane or coating. The cavity can contain an active substance in liquid or solid form, or as a molecular dispersion. NC zeta-potential (ZP) is an important index for the stability of a nanoparticle suspension, representing the electric potential at the NC shear plane, that depends on the chemical nature of the polymer and stabilizing agent, and the medium $\mathrm{pH}$ (13). A high absolute value of ZP indicates a high surface electrical charge, which can cause strong repellent forces among the particles and prevent aggregation in solution. It is also important in determining the in vivo interaction of the NC with the cell membrane, which is usually negatively charged (14). Some of the current strategies employing NC for cancer treatment research are summarized in Table 1.

NCs can be produced by two approaches: selfassembly and template-based. In self-assembly, lipid molecules or amphiphilic block copolymers can aggregate in aqueous solution into vesicular structures and the hollow sphere morphology of these aggregates makes them suitable precursors for the preparation of stable NC formulations by using different reactions. In the template approach, a polymer shell is formed around a template particle that can subsequently be removed, leaving an empty polymeric shell (15). Alternatively, core particles can be synthesized by conventional emulsion polymerization, followed by the addition of a different monomer that results in the formation of a cross-linked shell around a core particle, followed by the removal of the core particles (15). Illustrations of nanocapsular structures are presented in Figure 1.

In the process of the polyelectrolyte (PE) selfassembly on charged surfaces, hollow capsules are prepared via the layer-by-layer ( $\mathrm{LbL}$ ) technique, typically formed by the consecutive deposition of complementary/ interacting polymers onto colloidal particles, followed by removal of the sacrificial template (16). However, to avoid $\mathrm{PE}$-induced particle flocculation it is necessary to use low particle concentrations and unadsorbed PE has to be carefully removed after each step (15).

The principle of LbL coating is to sequentially expose the substrate to be coated to solutions containing either negatively or positively charged PEs. Adsorption of the $P E s$ is based on electrostatic interactions originating from the charged nature of the substrate and the PEs. Thickness and properties of the coating film can be controlled by the number and composition of the layers and the process conditions. After each coating layer, removal of excess PE can be achieved by different methods. Tangential flow filtration has been proposed for the intermediate purification of the NC dispersion during the LbL process and is a convenient method that retains $\mathrm{NC}$ integrity throughout successive purification steps, and does not involve the use of toxic solvents or harsh conditions (17). In addition, a versatile technique for drug encapsulation involves the adsorption of the drug within a porous particle that can subsequently be LbL-coated, and the template (e.g., silica) can be removed, resulting in the formation of NCs with high loading capacities (16).

In many cancer treatments, particularly for brain tumors, it is difficult to deliver the therapeutic agents to the tumor site and to the infiltrating tumor cells. Therefore, new devices are being developed to facilitate intratumoral distribution, to protect the active agent from premature degradation and to allow its sustained and controlled release. In the following sections, recent studies on the use of NCs in cancer are presented according to their particular NC formulations. However, this division is somewhat arbitrary since the NCs can be assigned to more than one section.

\section{Lipid nanocapsules}

Lipid nanocapsules (LNCs) are nanovectors with biomimetic properties that are produced through a phase inversion temperature process following the formation of an oil/water microemulsion. The process relies on at least three main components: an oily phase, an aqueous phase and a nonionic surfactant. LNC structure consists of an oily liquid triglyceride core surrounded by a tensioactive cohesive interface (18). Changes in the proportions of triglycerides, lecithin, salt-water, and polyethylene glycol (PEG) hydroxystearate lead to different sized formulations 
Table 1. Recent strategies for cancer treatment using nanocapsules.

\begin{tabular}{|c|c|c|c|c|c|c|c|}
\hline Strategies & $\begin{array}{l}\text { Encapsulated } \\
\text { molecule }\end{array}$ & $\begin{array}{l}\text { Encapsulation } \\
\text { rates }\end{array}$ & $\begin{array}{l}\text { Particle } \\
\text { size }\end{array}$ & $\begin{array}{c}\text { Zeta } \\
\text { potential }\end{array}$ & Study designs & Results & Reference \\
\hline Antitumor effect & $\begin{array}{l}\text { Ferrociphenol } \\
\text { (Fc-diOH) }\end{array}$ & $\begin{array}{l}6.5 \mathrm{mg} / \mathrm{g}, 2 \% \\
\text { dry weight }\end{array}$ & $44-53 \mathrm{~nm}$ & $\begin{array}{l}\text { From }-3 \\
\text { to }-5 \mathrm{mV}\end{array}$ & $\begin{array}{l}\text { Orthotopic gliosar- } \\
\text { coma model. }\end{array}$ & $\begin{array}{l}\text { Increased survival } \\
\text { time of tumor- } \\
\text { bearing rats. }\end{array}$ & (27) \\
\hline $\begin{array}{l}\text { Delivery of } \\
\text { foreign genetic } \\
\text { material to } \\
\text { target cells }\end{array}$ & DNA & & $\begin{array}{l}117- \\
142 \mathrm{~nm} \\
\text { (different } \\
\text { coatings) }\end{array}$ & $\begin{array}{l}\text { From } \\
+30 \text { to } \\
-941 \mathrm{mV}\end{array}$ & $\begin{array}{l}\text { In vitro macrophage } \\
\text { uptake evaluation; } \\
\text { Complement activa- } \\
\text { tion study; In vivo } \\
\text { hepatotoxicity study } \\
\text { after iv injection; } \\
\text { Blood kinetic study. }\end{array}$ & $\begin{array}{l}\text { Inhibition of comple- } \\
\text { ment activation; } \\
\text { Increase of in vivo } \\
\text { circulation time and } \\
\text { tumor accumulation. }\end{array}$ & (26) \\
\hline $\begin{array}{l}\text { Antiangiogenesis } \\
\text { and anticancer } \\
\text { drugs } \\
\text { sequentially }\end{array}$ & $\begin{array}{l}\text { Paclitaxel (PTX) } \\
\text { and combretastatin } \\
\text { A4 (CA4) }\end{array}$ & $\begin{array}{l}27.2 \text { and } \\
20.7 \%\end{array}$ & $180 \mathrm{~nm}$ & - & $\begin{array}{l}\text { In vitro drug release; } \\
\text { Apoptosis assay; } \\
\text { Immunofluorescence } \\
\text { staining of tubulin dis- } \\
\text { ruption; Cellular } \\
\text { uptake by human } \\
\text { umbilical vein } \\
\text { endothelial cells. }\end{array}$ & $\begin{array}{l}\text { Temporal ablation of } \\
\text { endothelial cells and } \\
\text { cancer cells. }\end{array}$ & (54) \\
\hline Antitumor effect & $\begin{array}{l}\text { Camptothecin } \\
(\mathrm{CPT}) \text { and } \\
\text { doxorubicin salt } \\
(\mathrm{DOX} \cdot \mathrm{HCl})\end{array}$ & 40 or $58 \%$ wt & $\begin{array}{l}132 \text { and } \\
192 \mathrm{~nm}\end{array}$ & - & $\begin{array}{l}\text { In vitro cytotoxicity on } \\
\text { SKOV-3 and MCF-7 } \\
\text { cancer cell lines; In } \\
\text { vivo antitumor activity } \\
\text { on mice bearing intra- } \\
\text { peritoneal tumors. }\end{array}$ & $\begin{array}{l}\text { High in vitro and in } \\
\text { vivo antitumor activity. }\end{array}$ & $(72)$ \\
\hline $\begin{array}{l}\text { Overcoming } \\
\text { multidrug } \\
\text { resistance }\end{array}$ & PTX & $70 \% \mathrm{wt}$ & $\begin{array}{l}150 \pm \\
50 \mathrm{~nm}\end{array}$ & - & In vitro cell assays. & $\begin{array}{l}\text { Enhanced cell } \\
\text { growth inhibition in a } \\
\text { multidrug-resistant } \\
\text { ovarian cancer cell } \\
\text { line. }\end{array}$ & (50) \\
\hline Antitumor effect & PTX & $9.58 \% \mathrm{wt}$ & $280 \mathrm{~nm}$ & - & $\begin{array}{l}\text { In vitro inhibition of } \\
\text { cell growth; Confocal } \\
\text { microscopy and cell } \\
\text { cycle analysis; In vivo } \\
\text { tumor accumulation, } \\
\text { biodistribution, and } \\
\text { antitumor effect. }\end{array}$ & $\begin{array}{l}\text { Preferential accumu- } \\
\text { lation at the tumor } \\
\text { site and suppression } \\
\text { of tumor growth. }\end{array}$ & (61) \\
\hline $\begin{array}{l}\text { Combinatorial } \\
\text { sequential drug } \\
\text { delivery system } \\
\text { for antiangio- } \\
\text { genesis and } \\
\text { anticancer } \\
\text { activities }\end{array}$ & $\begin{array}{l}\text { CA4 in a matrix } \\
\text { made up of } \\
\text { conjugated PTX }\end{array}$ & $52 \%$ & $\begin{array}{l}68.3 \pm \\
1.4 \mathrm{~nm}\end{array}$ & - & $\begin{array}{l}\text { Biodistribution experi- } \\
\text { ments; In vivo artificial } \\
\text { proangiogenesis and } \\
\text { tumor xenograft } \\
\text { assays; Intrasplenic } \\
\text { liver metastasis } \\
\text { experiment. }\end{array}$ & $\begin{array}{l}\text { Efficient cellular } \\
\text { uptake; Long circula- } \\
\text { tion in body fluid and } \\
\text { accumulation in } \\
\text { tumor; Therapeutic } \\
\text { effect on tumor } \\
\text { vasculature disrup- } \\
\text { tion, tumor cell } \\
\text { proliferation and } \\
\text { apoptosis induction; } \\
\text { Liver metastatic } \\
\text { prevention capacity. }\end{array}$ & (55) \\
\hline $\begin{array}{l}\text { Expression of } \\
\text { CK2 subunits } \\
\text { and CK2 effects } \\
\text { on mediated } \\
\text { signal activation } \\
\text { and gene } \\
\text { expression }\end{array}$ & $\begin{array}{l}\text { Anti-CK } 2 \alpha / \alpha^{\prime} \\
\text { oligodeoxynucleo- } \\
\text { tide }\end{array}$ & $90 \%$ & $\begin{array}{l}\text { Sub- } \\
50 \mathrm{~nm}\end{array}$ & - & $\begin{array}{l}\text { Western blot; } \\
\text { Immunohistochemistry; } \\
\text { siRNA; Luciferase } \\
\text { reporter assays; } \\
\text { Quantitative PCR; } \\
\text { MTT; Flow cytometry; } \\
\text { Migration assays; In } \\
\text { vivo xenograft models. }\end{array}$ & $\begin{array}{l}\text { Suppression of } \\
\text { tumor growth; Down- } \\
\text { modulation of NF-kB } \\
\text { and up-modulation of } \\
\text { TP53; Induction of } \\
\text { apoptosis; Efficacy } \\
\text { enhancement of } \\
\text { cisplatin-based } \\
\text { chemotherapy; } \\
\text { Downregulation of } \\
\text { CK2 in HNSCC } \\
\text { models in vitro and } \\
\text { in vivo. }\end{array}$ & $(77)$ \\
\hline $\begin{array}{l}\text { Cytotoxic } \\
\text { effects of } \\
\text { MIAMI cells } \\
\text { loaded with } \\
\text { LNCs. }\end{array}$ & Fc-diOH & $\begin{array}{l}2.6 \pm \\
0.1 \mathrm{mg} / \mathrm{mL}\end{array}$ & $\begin{array}{l}76 \pm \\
2 \mathrm{~nm}\end{array}$ & $\begin{array}{l}-7 \pm \\
2 \mathrm{mV}\end{array}$ & $\begin{array}{l}\text { In vitro uptake of } \\
\text { LNCs by MIAMI cells; } \\
\text { In vitro toxicity on } \\
\text { U87MG cells; In vivo } \\
\text { toxicity after intratu- } \\
\text { moral injection in a } \\
\text { heterotopic U87MG } \\
\text { glioma model. }\end{array}$ & $\begin{array}{l}\text { MIAMI cells interna- } \\
\text { lized Fc-diOH-LNCs } \\
\text { with no induction of } \\
\text { MIAMI cell death, } \\
\text { and FC-diOH-LNC- } \\
\text { loaded MIAMI cells } \\
\text { showed a cytotoxic } \\
\text { effect. }\end{array}$ & (36) \\
\hline
\end{tabular}

Continued on next page 
Table 1. Continued.

\begin{tabular}{|c|c|c|c|c|c|c|c|}
\hline Strategies & $\begin{array}{l}\text { Encapsulated } \\
\text { molecule }\end{array}$ & $\begin{array}{l}\text { Encapsulation } \\
\text { rates }\end{array}$ & $\begin{array}{l}\text { Particle } \\
\text { size }\end{array}$ & $\begin{array}{c}\text { Zeta } \\
\text { potential }\end{array}$ & Study designs & Results & Reference \\
\hline $\begin{array}{l}\text { Hepatoma- } \\
\text { targeted gene } \\
\text { delivery system }\end{array}$ & $\begin{array}{l}\text { PKC } \alpha \text {-specific } \\
\text { substrate peptide }\end{array}$ & $\begin{array}{l}0.9 \text { and } 1.2 \\
\text { mol\% }\end{array}$ & $<100 \mathrm{~nm}$ & - & $\begin{array}{l}\text { Human tumor xeno- } \\
\text { grafted mice; Gene } \\
\text { expression in hepa- } \\
\text { toma cells and tissues } \\
\text { and human hepato- } \\
\text { cytes or epidermoid } \\
\text { tumor cells. }\end{array}$ & $\begin{array}{l}\text { Increased transfec- } \\
\text { tion efficiency; Cell- } \\
\text { specific gene } \\
\text { expression in } \\
\text { hepatoma cells and } \\
\text { tissues. }\end{array}$ & (81) \\
\hline $\begin{array}{l}\text { Internal radiation } \\
\text { with LNC }{ }^{188} \mathrm{Re}- \\
\text { SSS }\end{array}$ & Rhenium-188 & $\begin{array}{l}\text { approxi- } \\
\text { mately } 97 \%\end{array}$ & $\begin{array}{l}49.7 \pm \\
2.7 \mathrm{~nm}\end{array}$ & - & $\begin{array}{l}\text { Chemically induced } \\
\text { hepatocellular carci- } \\
\text { noma rat model; } \\
\text { Biodistribution study } \\
\text { following hepatic } \\
\text { artery injection; } \\
\text { Survival evaluation. }\end{array}$ & $\begin{array}{l}\text { Increase in the } \\
\text { median survival in } \\
\text { treated rats; } \\
\text { Decreased vascular } \\
\text { endothelial growth } \\
\text { factor expression. }\end{array}$ & (37) \\
\hline $\begin{array}{l}\text { Mitochondrial } \\
\text { targeting }\end{array}$ & $\begin{array}{l}\text { SV30, an analo- } \\
\text { gue of the pro- } \\
\text { apoptotic mole- } \\
\text { cule HA14-1 }\end{array}$ & $92 \pm 20 \%$ & $\sim 57 \mathrm{~nm}$ & $\sim-10 \mathrm{mV}$ & $\begin{array}{l}\text { In vitro survival } \\
\text { assays; Western } \\
\text { blots; HPLC; Flow } \\
\text { cytometry; Confocal } \\
\text { microscopy; Spectral } \\
\text { imaging. }\end{array}$ & $\begin{array}{l}\text { Improved SV30 } \\
\text { biological activity. }\end{array}$ & (38) \\
\hline $\begin{array}{l}\text { Photodynamic } \\
\text { therapy }\end{array}$ & Cyanine IR-768 & $\begin{array}{l}\text { from } 65.7 \text { to } \\
91.7 \% .\end{array}$ & $\begin{array}{l}\text { from } 192 \\
\text { to } \\
642 \mathrm{~nm}\end{array}$ & $\begin{array}{l}\text { from } \\
\sim-23 \text { to } \\
\sim-41 \mathrm{~V}\end{array}$ & $\begin{array}{l}\text { In vitro erythrocyte } \\
\text { hemolysis; Cell viabi- } \\
\text { lity of breast cancer } \\
\text { MCF-7 cells; } \\
\text { Fluorescence micro- } \\
\text { scopy. }\end{array}$ & $\begin{array}{l}\text { Efficient delivery to } \\
\text { DOX-sensitive and } \\
\text { resistant cells; } \\
\text { Decreased cell } \\
\text { viability by photoirra- } \\
\text { diation with an } \\
\text { entrapped } \\
\text { photosensitizer. }\end{array}$ & $(60)$ \\
\hline $\begin{array}{l}\text { Chemokine } \\
\text { delivery }\end{array}$ & $\begin{array}{l}\text { Lymphoid chemo- } \\
\text { kine CCL21 }\end{array}$ & $\begin{array}{l}20-30 \text { mole- } \\
\text { cules of the } \\
\text { CCL21-INT/ } \\
\text { particle }\end{array}$ & $\begin{array}{l}40 \mathrm{~nm} \text { in } \\
\text { width and } \\
70 \mathrm{~nm} \text { in } \\
\text { length }\end{array}$ & - & $\begin{array}{l}\text { Intratumoral adminis- } \\
\text { tration of CCL21- } \\
\text { vaults in mice bearing } \\
\text { lung cancer. }\end{array}$ & $\begin{array}{l}\text { Inhibition of tumor } \\
\text { growth and reduction } \\
\text { of immune suppres- } \\
\text { sive and T-regulatory } \\
\text { cells; Induction of } \\
\text { systemic antitumor } \\
\text { responses. }\end{array}$ & (82) \\
\hline $\begin{array}{l}\text { Magnetically } \\
\text { triggered siRNA } \\
\text { delivery }\end{array}$ & siRNA & & $500 \mathrm{~nm}$ & - & In vitro cell assays. & $\begin{array}{l}\text { Efficient intracellular } \\
\text { uptake and silencing } \\
\text { effect of siRNA upon } \\
\text { exposure to a } \\
\text { magnet. }\end{array}$ & (65) \\
\hline $\begin{array}{l}\text { Intracellular } \\
\text { protein delivery }\end{array}$ & Caspase 3 & & $11.3 \mathrm{~nm}$ & $\begin{array}{l}3.6 \pm \\
0.1 \mathrm{mV}\end{array}$ & $\begin{array}{l}\text { In vitro assays; } \\
\text { Cellular uptake, inter- } \\
\text { nalization and traffick- } \\
\text { ing; Cytotoxicity and } \\
\text { apoptosis assays. }\end{array}$ & $\begin{array}{l}\text { Efficient internaliza- } \\
\text { tion and releasing } \\
\text { the active protein in } \\
\text { reducing cytosol; } \\
\text { Induction of } \\
\text { apoptosis. }\end{array}$ & (71) \\
\hline
\end{tabular}

MIAMI = marrow-isolated adult multilineage inducible; LNCs $=$ lipid nanocapsules

of LNCs, ranging from 20 to $100 \mathrm{~nm}$, depending on the quantity of excipients, with a narrow distribution (19). No organic solvent is used during the formulation and all the excipients are FDA approved.

LNCs are characterized as a hybrid structure between polymer NCs and liposomes, with the advantages of greater stability and a solvent-free manufacturing process compared to liposomes. Moreover, the temperature cycling process crossing the phase inversion zone plays a relatively important role in LNC formulation. Reducing the amount of surfactant increases the number of temperature cycles required to stabilize dispersion (20). In general, LNCs have a negative surface charge due to the phospholipid molecules (21) and the presence of PEG dipoles in their shell, which are able to reduce the surface charge in proportion to their concentration (22). The efficient encapsulation of drugs in the oily core of LNCs can be denoted by no significant modification of the average particle size and ZP.

In addition to their efficient drug-loading capacity, LNCs show adjuvant effects, such as P-gp inhibition properties, which can favor higher anticancer drug concentrations inside cancer cells (23). The in vitro gastrointestinal stability of LNCs was studied to evaluate the applicability of oral administration of anticancer drugs. The LNCs were stable in simulated gastric medium and fasted state intestinal medium (24).

LNCs appear to satisfy the properties required for weak complement activation and low macrophage uptake, resulting in an increased bloodstream circulation time due to their nanoscale size range and their high-density PEG surfactant shell (20). Introducing surfactants in the post- 

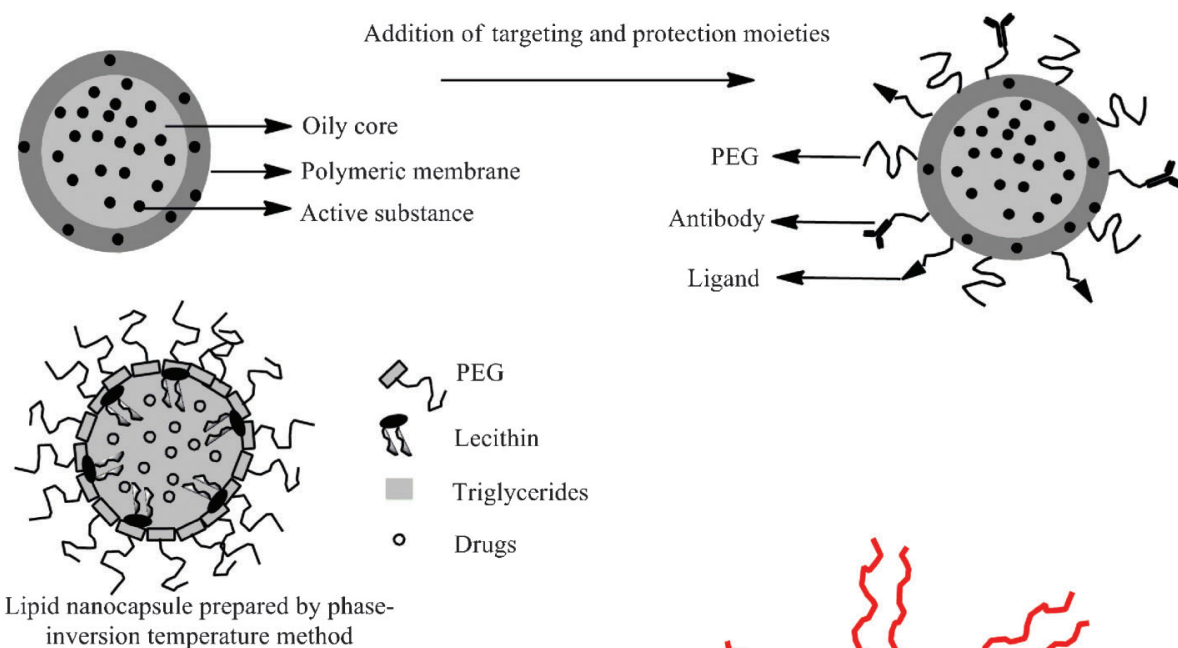

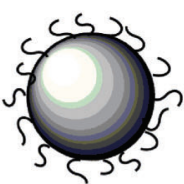

DNA LNC

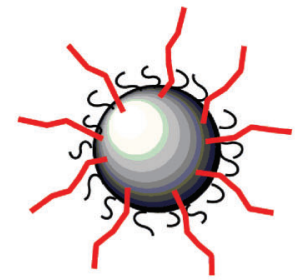

DNA LNC + DSPE-mPEG2000
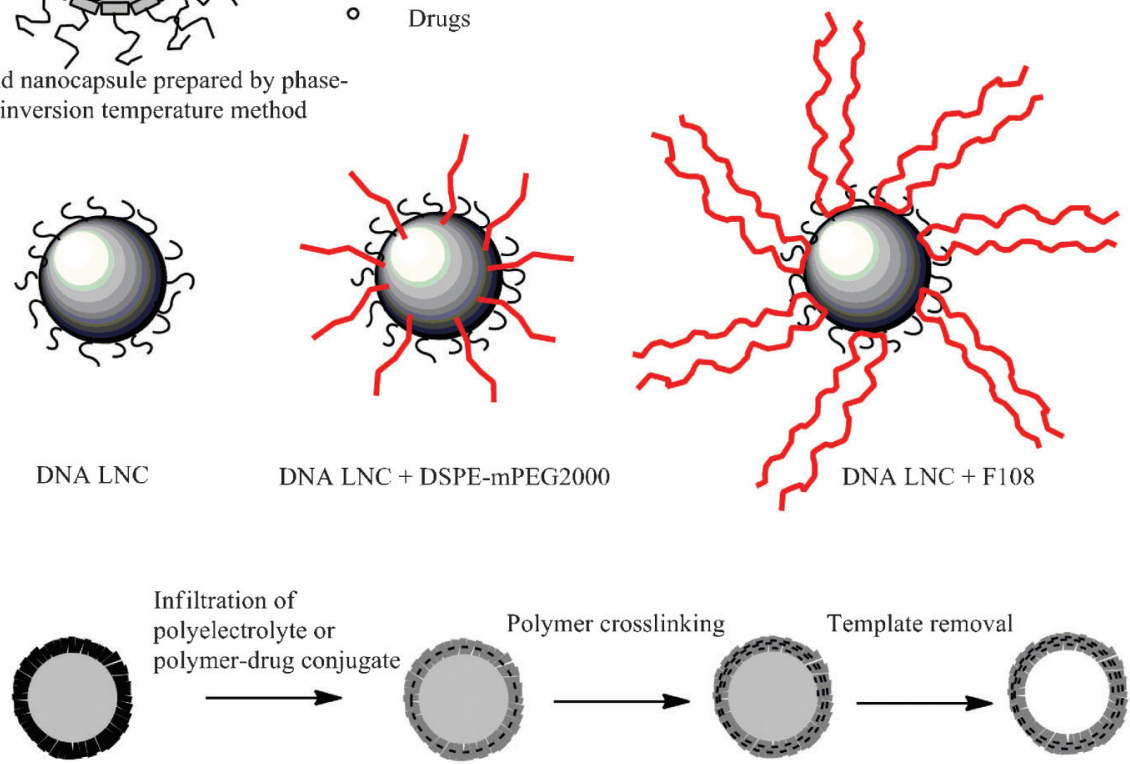

Solid core-mesoporous shell nanoparticle
Crosslinked polymer or polymer-drug nanocapsule

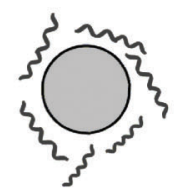

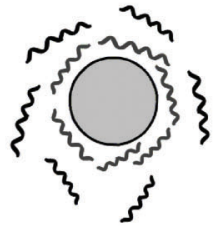
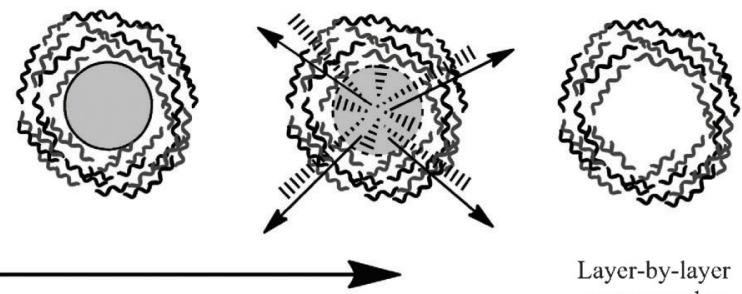

Layer-by-layer nanocapsules

Layer-by-layer deposition of oppositely charged polyelectrolytes followed by template decomposition

Figure 1. Schematic examples of nanocapsular structures. PEG = polyethylene glycol; LNC = lipid nanocapsules; DESPEmPEG2000 = 1,2-distearoyl-sn-glycero-3-phosphoethanolamine- $\mathrm{N}$-[methoxy-(polyethyleneglycol)-2000].

insertion process alters the surface properties of the nanoparticles. Grafting longer PEG chains, such as PEG 1500 instead of PEG 660, prolonged their circulation time (25). Although the long-circulating properties of LNCs coated with DSPE-mPEG2000 (1,2-distearoyl-sn-glycero3-phospho-ethanolamine-N-[methoxy-(polyethyleneglycol)-
2000]) have been demonstrated (26), the abundant presence of PEG, especially with long chains on the nanoparticulate surface, can inhibit the internalization of drug-loaded $\mathrm{NCs}$, possibly by preventing interactions between the NCs and the tumor cell surface (27).

Experimental results obtained by Perrier et al. (28) 
indicate that DSPE-PEGs are efficiently transferred from micelles to LNCs during the process by a temperature-dependent molecular transfer. The hydrodynamic diameter (HD) increased from 55 to $70 \mathrm{~nm}$ at $5 \%$ DSPE-PEG2000-OCH3. Concentrations greater than 5\% had no effect on increasing the HD and an upper limit of $70 \mathrm{~nm}$ was observed. In addition, the ZP decreased with the amount of DSPE-PEG2000-OCH3, suggesting that additional DSPE-PEG molecules were still interacting with the LNC. The HD increased with the length of the PEG chain, although less than predicted by an assumption of linear conformation, indicating that the PEG chains interact strongly in a compact conformation. The variation of PEG chain length and subsequent purification by dialysis determined the limits for post-insertion in terms of the nature of transferred amphiphiles. In the case of highly hydrophilic molecules, post-insertion can be reversible and incomplete (28).

In the gene delivery field, the most commonly used polynucleotide lipid-based carriers are lipid-DNA complexes, called lipoplexes. These are obtained by mixing cationic liposomes with DNA. However, an excess of cationic lipids can lead to high cytotoxicity (29). Viral vectors are still used for gene expression, despite having several drawbacks. Therefore, LNCs are good candidates for an efficient DNA delivery system, as NCs are an alternative for the maintenance of nucleic acid integrity required for efficient gene delivery in cancer therapy. LNCs provide protection by entrapping plasmid DNA molecules via lipoplexes in their lipid core, and DNAcoated LNCs have been shown to be stable. DNA molecules can be encapsulated and protected against degradation, as demonstrated by Morille et al. (26). Analysis by agarose gel electrophoresis showed that there was no DNA migration after NC formulation followed by a post-insertion process, whereas when incubated with a detergent (Triton), DNA molecules were released, migrating unaltered into the gel.

To increase the stability for efficient in vivo DNA transfection, the surface of the LNCs was modified by inserting longer PEG chains onto the surface of DNALNCs by post-insertion of two kinds of amphiphilic and flexible polymers. The first was F108, a block copolymer, and the second was the lipid PEG derivative DSPEmPEG2000. Measurements of the ZP found that DNALNCs were able to partially mask the positive charge due to the presence of the lipoplexes (30). The two polymers DSPE-PEG2000-gal and F108-gal were obtained by chemical and enzymatic galactosylation, respectively. The DNA-LNCs were tested for in vitro transfection efficiency on primary hepatocytes. This study confirmed that galactose moieties were accessible on the surface of galactosylated DNA-LNCs coated with F108, and this effect was less pronounced in galactosylated DNA-LNCs coated with DSPE-PEG2000. The F108-gal coating improved gene delivery compared to F108 without galactose. The addition of galactose to DSPE-PEG2000 did not improve transfection efficiency, probably due to the insufficient accessibility of galactose when attached to this polymer. Therefore, DNA-LNCs coated with F108-gal can be used for targeted-gene expression based on a cellspecific, receptor-mediated, endocytosis process.

The in vivo tumoral transfection potential of amphiphilic DSPE-mPEG2000- and poloxamer F108-coated NCs was tested in a mouse tumor model, demonstrating that DNA-LNCs can be efficient in transfecting tumor tissues in vivo if coated with DSPE-mPEG2000 in association with a special PEG chain conformation (31). Coating with F108 or DSPE-mPEG2000 increased the $\mathrm{HD}$, evidence of an association between the DNA-LNCs and the post-inserted polymers. The size increase, when adding DSPE-mPEG2000 at any concentration to the DNA-LNC surface, ranged from 11 to $20 \mathrm{~nm}$, indicating a probable extended chain conformation. By contrast, the size increase due to $\mathrm{F} 108$ post-insertion was smaller (about $15 \mathrm{~nm}$ ), even though the F108 polyethylene oxide chains are 3 times longer than those of the DSPEmPEG2000. These results suggest a probable coiled configuration of the F108 chains that allowed some accessibility of hydrophobic moieties on the DNA-LNC surface. The decreased surface-charge density was observed for both polymers, but was more marked for the DSPE-mPEG2000 coating, with a charge decrease from positive to negative values. Two surface layer parameter measurements (spatial charge density and softness) indicated that the DSPE-mPEG2000 coating was organized in a brush conformation, while F108 had adopted a super-coiled conformation (31).

F108-coated NCs had a dramatically increased transfection rate in vitro (30); however, the F108 coating did not expose any transfection in tumor tissues in vivo (31). This can be linked to its interaction with other organs before acceding to the tumor site. As attested by Morille et al. (26), F108 has a shorter half-life in blood than DSPEmPEG2000-coated DNA-LNCs. A major difference between gene expression in tumor tissue and in other organs was observed for DNA-LNCs coated with DSPEmPEG2000, with only minor transfection observed in other organs (including elimination organs). The in vivo chain conformation of DSPE-mPEG2000 probably allowed sufficient accumulation via the EPR effect. At the tumor site, in vivo gene expression was possible despite the low transfection levels observed in vitro (31).

LNCs are suitable for local treatment, including direct intracranial drug delivery, thereby eliminating the need for a chemotherapeutic agent to bypass the blood-brain barrier (BBB). The convection-enhanced delivery (CED) technique, using an external positive pressure gradient injecting therapeutic fluid in the brain, allows a greater volume distribution to be achieved in comparison to diffusion alone (32). Therefore, LNCs with drug-loaded core delivered by the CED technique appear to be a 
promising approach for the treatment of brain tumors (27). Overcoming problems related to short drug tissue retention times or heterogeneous distribution, nanoencapsulation may offer advantages such as protection of the active species, reduced brain toxicity, a better drug distribution, and a longer half-life. Alternatively, the route of administration by intracarotid injection may also represent a promising path for drug delivery to brain tumors by giving the nanoparticles a greater chance to cross the BBB (27).

Ferrocifen-type molecules, obtained by attaching a ferrocenyl unit onto a tamoxifen skeleton in order to enhance its cytotoxicity, are anticancer drug candidates (33), although they suffer from poor bioavailability due to their highly hydrophobic phenol groups. These hydrophobic bioorganometallic molecules, which contain at least one carbon directly bound to a metal or metalloid, can be active in glioblastoma multiform therapy, but their water insolubility can impede their potential biological activity. Allard et al. (34) have shown that it is possible to formulate these molecules in LNCs. LNCs loaded with the ferrocenyl diphenol compound called "ferrociphenol" (Fc$\mathrm{diOH}$ ), one of the most active molecules in this new class of organometallic drugs, proved to be effective against $9 \mathrm{~L}$ glioma cells and in a $9 \mathrm{~L}$ animal model and exhibited advantages over swollen micelles, which are smaller sized particles produced by a similar process with the same excipients (34).

LNCs were rapidly taken up by $9 \mathrm{~L}$ cells, while micelles were taken up at much lower levels. Although smaller than the LNCs, the presence of a high-density PEG coating likely decreased the interaction of the swollen micelles with cells, resulting in low internalization. This suggested that the LNCs improved the intracellular bioavailability of the $\mathrm{Fc}-\mathrm{diOH}$, which had a much higher cytotoxic activity than empty LNCs, and also demonstrated a higher cytotoxic effect in glioma cells than in astrocytes. In the in vivo glioma model, $\mathrm{Fc}$-diOH-loaded LNCs significantly inhibited tumor growth and this was not observed in rats treated with $\mathrm{Fc}$-diOH-loaded micelles (34).

The activity of the Fc-diOH-LNCs was evaluated in 9L cells in association with radiotherapy (RT) and a combined treatment using the CED of Fc-diOH-LNCs with external beam RT was evaluated in 9L gliomabearing rats (35). For the combined RT, sucrose was dissolved in the aqueous phase of the LNC suspension after formulation, to enhance the viscosity of the infusion, and its presence did not affect the LNC size and had no toxic effect on cells in vitro. The treatment was more efficient when cells were first treated with $\mathrm{Fc}$-diOH followed by RT, improving survival time compared to all other treatments and the control groups. The treatment combination in such order showed synergy and not only an additive effect, and the radiosensitizing effect of Fc$\mathrm{diOH}$ may explain this enhanced efficacy. The synergy between the organometallic compounds and RT indicated a potential therapeutic application for this class of molecules, which often suffer from bioavailability problems. In the intracranial in vivo model, the $\mathrm{Fc}-\mathrm{diOH}-$ loaded LNCs with the highest dose entrapped were administered to $9 \mathrm{~L}$ glioma-bearing rats by the CED, followed by external RT. This resulted in a significant increase in median survival time compared to the chemotherapy group, to the group treated with empty LNCs followed by the same irradiation protocol, and to the group treated only with RT (35).

The identification of a subpopulation of human mesenchymal stromal cells, called "marrow-isolated adult multilineage inducible" (MIAMI) cells that could be used as delivery vehicles, was used to evaluate the therapeutic efficacy of MIAMI cells carrying Fc-diOH-LNCs (36). Internalization of the drug-loaded LNCs did not affect MIAMI cell viability, and MIAMI cells loaded with Fc-diOHLNCs were cytotoxic to glioma cells. The Fc-diOH-LNCloaded MIAMI cells induced a significant, dose-dependent, inhibition of U87MG cell proliferation, which suggested that the MIAMI cells were able to deliver the $\mathrm{Fc}$-diOH or Fc$\mathrm{diOH}-\mathrm{LNCs}$. Furthermore, this cytotoxic effect was confirmed in vivo in a heterotopic U87MG glioma model. Although the authors successfully demonstrated that the MIAMI cells were able to efficiently internalize the drug-loaded LNCs while remaining viable, and deliver the drug-loaded LNCs into tumors, the effects of Fc-diOHLNC-loaded MIAMI cells and those of Fc-diOH-LNCs alone were not compared (36).

Tumor-targeting nanoscale vectors able to deliver radionuclides have been recently developed. The LNCs permit the encapsulation of a lipophilic complex of Rhenium-188 $\left({ }^{188} \mathrm{Re}\right)$, and Vanpouille-Box et al. (37) reported the $\mathrm{LNC}^{188} \mathrm{Re}-\mathrm{SSS}$ as a radiopharmaceutical carrier for internal RT in rats with hepatocellular carcinoma. No intolerance following $L N C^{188}$ Re-SSS intraarterial injection was observed, and therapeutic efficiency was evidenced by a reduction in tumor progression. This could be combined with an altered angiogenesis process as indicated by lower vascular endothelial growth factor (VEGF) levels. In addition, an increase in the median survival and preservation of healthy liver tissue compared to control groups was observed.

Novel LNC formulations towards the development of new mitochondria-targeted medicines have been proposed to improve the administration and biological activity of an analogue of the pro-apoptotic molecule HA14-1 (38). HA14-1 was designed to inhibit Bcl-2/Bax interactions and thus stimulate apoptosis (39). Subsequently, due to the instability of the molecule, a more stable analogue of HA14-1, called SV30, was prepared (40) and evaluated against glioma cells (38). SV30 was incorporated into LNCs at a high encapsulation rate, and its stability was maintained during the formulation process. Of note, unlike the other studies mentioned in this section, LNC size was 
affected by the loading of the lipophilic drug, resulting in a $20 \%$ increase compared to unloaded LNCs. Thus, LNC size and, more discretely, ZP modifications postencapsulation combined with the relatively fast release of SV30 suggested that the drug might also be present on the external shell of the LNCs (38). Empty LNCs had no effect on glioma cells, while the SV30-LNCs triggered a 2-fold increase in cancer cell death compared to free SV30. In addition, the nanoformulation was stable for at least 1 month at $4^{\circ} \mathrm{C}$. The potential of LNCs to carry two different molecules was exploited to load a fluorescent probe, but could also have been used to load another synergistic drug. The labeled LNCs were used to confirm the ability of the SV30-LNCs to reach the mitochondria, which represent a major intracellular target for cell death induction and Bcl-2-related inhibition. The LNCs were able to accumulate next to the mitochondria, and the SV30-LNCs were more potent than empty-LNCs to do so. Thus, interactions of $\mathrm{Bcl}-2$ (or a Bcl-2 family member) with SV30 and SV30-LNCs may have triggered specific modifications of subcellular trafficking pathways resulting in $L N C$ redistribution within cells (38).

Paclitaxel (PTX) is a major antineoplastic agent with widespread antitumor activity, but presents administration issues. Lacoeuille et al. (41) demonstrated the increased circulating properties of LNC and the therapeutic efficiency of PTX-LNC compared to controls in a hepatocellular carcinoma model. The PTX-LNCs had the advantage of avoiding the conventional use of Cremophor EL for the solubilization and formulation of PTX, which is associated with severe side effects. Therefore, PTX-LNC has been proposed as a new drug delivery system for PTX (41). The LNCs were evaluated as new pulmonary delivery strategies, and the incorporation of the drug into breathable droplets for pulmonary delivery by nebulization is a potential therapeutic strategy with reduced systemic side effects. In this context, Hureaux et al. (42) demonstrated that PTX-LNCs could be delivered by nebulization and the physical and chemical parameters were optimized for aerosol delivery and storage.

The formulations were nonpyrogenic and remained sterile for up to 4 months, showing that PTX-LNC dispersions exhibited the principal parameters required for aerosol delivery in humans. Osmolarity and $\mathrm{pH}$ can be a problem for bronchial and alveolar cells; therefore, following $\mathrm{LNC}$ fabrication, the $\mathrm{pH}$ was increased to reach tissue $\mathrm{pH}$ by the addition of sodium hydroxide and the osmolarity was also increased to near-human isoosmolarity by adding sodium chloride. Ultimately, only one mesh nebulizer was able to produce aerosols of the PTX-LNC dispersions without damaging the LNCs and sustaining good characteristics for human use. Stability during storage is important in order to allow preclinical and clinical studies to take place. The freeze-storage protocol developed did not alter or damage the PTXLNCs. The cytotoxic effect of the stored PTX-LNCs was identical to that of the fresh PTX-LNCs, and the chemical parameters were not modified. As the PTX-LNCs are sustained-release drug nanocarriers that can be nebulized, the traditional limitations for the blood infusion of PTX, such as a low concentration in the lungs, insufficient drug delivery to tumor cells, resistance, and nonspecific distribution associated with systemic toxicity could be overcome with aerosols of PTX-LNCs in lung cancer patients (42).

More recently, Basile et al. (43) evaluated the protective effect of a new series of amphiphilic PEG derivatives obtained by conjugating either carboxy- or amine-PEG to lipoamino acid residues (LAA) on PTX-LNCs. Coated NCs were prepared by post-insertion. The behavior of the PEGLAA conjugate was also compared to commercial DSPE$\mathrm{mPEG}$ used to produce sterically stabilized vesicles. They investigated the ability of the novel amphiphilic PEG conjugate to stabilize colloidal drug carriers with respect to their permanence in the bloodstream, and found that it was possible to prepare sterically stable nanocarriers, although future studies will be needed to assess the potentiality of these nanocarriers.

\section{Layer-by-layer nanocapsules}

One of the goals of an LbL process is to improve the stability of the core particles (44) or the controlled release of an encapsulated substance (45). Typically, LbL particles are formed by consecutive deposition of interacting polymers onto particle templates, resulting in the formation of thin, multilayered polymer coatings on particles of different size, shape, composition, thickness, permeability, and function (46). Several templates can be used to deposit multiple layers, which are subsequently removed by chemical or thermal means to yield the polymer capsules. The nonporous templates include: inorganic molecular precursors that have been used to prepare inorganic capsules, liquid droplets, and gas bubbles. The porous templates include mesoporous silica (MS) and calcium carbonate particles, both of which can be decomposed under adequate conditions (47). Nonporous colloidal particles (48) are convenient templates for capsules with nanometer-thick walls, while with porous particle templates (49) polymer chains can infiltrate the core and, upon core dissolution, give rise to nanoporous polymer particles. Such nanoporous polymer particles can be used as high-load carriers of a desired molecule.

Since this method allows broad control of capsule properties through the choice of the sacrificial colloids and the film components, significant advances in the development of LbL particles have enabled efficient cargo encapsulation, triggered release, and antibody-mediated targeting (46). The feasibility of the LbL method improves the production of functionalized nanoparticles using polymers with free reactive groups for the outer layer. 
The sonication-assisted LbL nanoassembly technique can be used for the nanoencapsulation of poorly soluble anticancer drugs, and was exploited by Vergara et al. (50) to efficiently produce PTX-NCs. It was also used in the nanoformulation of two drugs in one NC, locating PTX in the core and lapatinib on the shell surface. Encapsulation increased the in vitro antitumor efficacy of PTX, which, in combination with lapatinib, significantly overcame multidrug resistance in ovarian cancer cell lines (50).

Son et al. (51) developed a new type of hollow NC for use in combining photodynamic therapy (PDT) with chemotherapy. PDT uses a combination of light and dyes or photosensitizers to induce damage in cancer cells and tissue (52). To produce the photosensitizer, a negatively charged dendritic porphyrin (DP) was synthesized and combined as a bilayer component with poly(allylamine hydrochloride) (PAH) to fabricate hollow NCs. While most NCs used in drug delivery system (DDS) are prepared from linear polyelectrolytes whose only function is as a drug container, this system employed DP not only as a polyelectrolyte component in the LbL assembly for the formation of NCs, but also as a photosensitizing agent for PDT. The amount of DP was controlled by changing the number of deposited layers. The (PAH/DP)n multilayer NCs were filled with the anticancer drug doxorubicin hydrochloride (DOX), producing NCs with both PDT and chemotherapeutic actions. DOX could diffuse easily through the multilayer shells to fill the hollow NCs, and the release profile resembled the loading profile. To control the release rate, the shells were cross-linked between $\mathrm{PAH}$ and $\mathrm{DP}$, and sustained release could be achieved by controlling the degree of cross-linking. Cell viability studies showed that the combined treatment resulted in higher toxicity than either chemotherapy or PDT alone (51).

\section{Core-shell nanocapsules}

Since tumor growth depends on the oxygen and nutrients supplied by tumor blood vessels, neovasculature in the tumor microenvironment is necessary for tumor pathogenesis (53). Therefore, targeting drugs directly to the tumor vasculature can provide an alternative therapy approach. However, there is evidence that tumor angiogenesis results from multiple associated and compensatory mechanisms, which could limit the therapeutic effects of a single antiangiogenesis therapy. Therefore, the therapeutic combination of a cytotoxic agent and an antiangiogenetic drug would probably enhance treatment (54). Moreover, a DDS that allows the sequential release of the antiangiogenic agent from the same carrier, followed by the cytotoxic drug, could lead to a more effective cancer treatment.

Wang and Ho (55) designed a tumor vasculaturetargeted, combinatorial, double self-assembled core-shell $\mathrm{NC}$, with the aim to sequentially disrupt tumor vascula- tures with combretastatin A4 (CA4), followed by induction of tumor cell apoptosis with PTX. The sequential drug release was accomplished by loading CA4 onto the lipid layer shell and PTX into the polymeric core. In addition, the arginine-glycine-aspartic acid (RGD peptide) was used as a vascular-targeting ligand, since the proliferating vascular endothelial cells of the tumor overexpress integrin receptors, $\alpha_{v} \beta_{3}$ and $\alpha_{v} \beta_{5}$, on the cell membrane. Thus, NCs could deliver drugs in a sustained and temporal manner to disrupt tumor vasculature and ablate tumor cells with the assistance of the RGD-targeting ligand (56).

The lipid-assisted nanoprecipitation method used in this study consisted of a one-step self-assembly process, where fewer chemicals and steps are involved, which makes the NC preparation simple and robust for large-scale production. The self-assembled PTX-loaded poly(lactic-co-glycolic acid) core surrounded by a hydrophilic PEG surface was coated with a lipid layer as a shell, and CA4 was loaded onto this lipid layer by hydrophobic interactions. The lipid shell served as a depot for CA4, as well as a molecular fence to control the release of PTX from the polymeric core, inducing cell death in a sequential manner (56).

An alternative design for an NC for the sequential delivery of CA4 and PTX employed the nanoprecipitation method using methoxyl PEG-poly(lactic acid) (mPEGPLA) as the building-up matrix. PTX was conjugated to PLA, and CA4 was encapsulated in the core when the mPEG-PLA self-assembled in an aqueous environment. This resulted in the production of uniform and stable nanoparticles exhibiting effective drug loading and sequential release of drugs. The in vitro evaluation of drug release showed a distinctive profile for PTX and CA4, with an initial fast release of CA4 followed by a sustained release. PTX was released in a sustained pattern with a slight peak on the first day of incubation, and longer incubation times accelerated the release of PTX from the NC, which was controlled by the slow hydrolysis of the ester bond between PTX and PLA (55).

Both in vitro and in vivo experiments have demonstrated significant therapeutic effects of dual-drug-loaded sequential-delivery NCs. The NCs accumulated in the tumor mass over time and no abnormalities were detected in the liver, kidney or heart of treated mice, and there were no apparent side effects. Cancer cell proliferation was reduced in the drug treatment group and there was no significant tumor cell metastasis, compared to the control groups (PBS and empty NCs). Although the exact therapeutic mechanism of these NCs is not clear, the induction of cellular apoptosis and antiangiogenesis activity was improved compared to single agent-loaded NCs. In addition, expression of VEGF, a major proangiogenesis factor in the tumor microenvironment, was inhibited (55).

The combination of physical imaging for cancer 
diagnosis and anticancer drug delivery into one system is of great interest. Multifunctional core/shell structured hollow MS NCs with ellipsoidal morphology for both MRI and drug delivery have been evaluated (57). Monodispersed ellipsoidal $\mathrm{Fe}_{2} \mathrm{O}_{3}$ nanocrystals were chosen as a template to obtain magnetic mesoporous NCs, which were fabricated by hydrothermal synthesis using iron perchlorate as the Fe precursor. A thick layer of dense silica was deposited onto the surface of $\mathrm{Fe}_{2} \mathrm{O}_{3}$ to form $\mathrm{Fe}_{2} \mathrm{O}_{3} @ \mathrm{SiO}_{2}$ core/shell nanostructures. A thin layer of MS shell was deposited onto the surface of the $\mathrm{Fe}_{2} \mathrm{O}_{3} @ \mathrm{SiO}_{2}$ to form a trilayered composite nanostructure $\left(\mathrm{Fe}_{2} \mathrm{O}_{3} @ \mathrm{SiO}_{2} @ \mathrm{mSiO}_{2}\right)$. The middle silica layer, with a lower degree of condensation, was etched away under alkaline conditions to form large cavities between the shell and core $\left(\mathrm{Fe}_{2} \mathrm{O}_{3} @ \mathrm{mSiO}_{2}\right)$. The outer MS shell (higher condensation degree) was maintained. Finally, the $\mathrm{Fe}_{2} \mathrm{O}_{3}$ core of the NCs was reduced in a gas mixture of $\mathrm{H}_{2}$ and $\mathrm{N}_{2}$ to produce hollow $\mathrm{Fe}_{3} \mathrm{O}_{4} @ \mathrm{mSiO}_{2}$ core/shell NCs with well-defined mesopores in the silica shell and controllable cavity sizes in the $\mathrm{NCs}(57)$. The $\mathrm{Fe}_{3} \mathrm{O}_{4} @ \mathrm{mSiO}_{2}$ nanocapsules demonstrated excellent blood compatibility and no significant coagulation effect was observed, ensuring biosafety for intravenous administration. There was no apparent in vitro cytotoxicity of the empty NCs even at high concentrations, and DOX could be loaded into the NCs with high efficiency, maintaining the pharmaceutical activities of the loaded DOX and enhancing its cytotoxicity against cancer cells (57).

\section{Polymeric and shell cross-linked nanocapsules}

To improve the conventional LbL technique for the preparation of NCs, Wang and Caruso (49) used a solid silica core and MS shell (SC/MS) template to prepare thick-walled, single-component polymer NCs. The process involved the infiltration of polyelectrolyte or polymer-drug conjugates into the mesoporous shells of the SC/MS particles, followed by cross-linking of the infiltrated polymer chains and subsequent removal of the SC/MS silica template, producing polyelectrolyte or drugconjugated polymer NCs. PAH was employed as the polyelectrolyte, glutaraldehyde was used as the crosslinking agent, and the SC/MS template was removed via treatment with hydrofluoric acid to obtain PAH NCs. For drug delivery applications, the preparation with polymers poly(L-amino acids), which are structurally related to natural proteins and considered to be biocompatible and biodegradable, was evaluated. Amine-functionalized positively charged SC/MS particles were used to adsorb poly(L-glutamic acid) (PGA) conjugated with DOX. The polymer-drug conjugate, PGA-DOX, was loaded into the mesoporous shells and cross-linked using 2,2' -diaminodiethyl disulfide dihydrochloride (cystamine) in the presence of 1-ethyl-3-(3-dimethylaminopropyl) carbodiimide hydrochloride. After removal of the SC/MS template, PGA-DOX NCs were obtained, and induced a significant decrease in the number of viable tumor cells in vitro, achieving $>85 \%$ cell death (49).

Polymeric NCs can be designed to encapsulate proteins that are protected against proteolysis and denaturation, and have increased efficiency in transport across the cell membrane. One strategy consisted of the development of protease-modulated reversible NCs, in which monomers and cross-linkers were deposited onto the protein surface via physical adsorption. Free-radical polymerization was performed in situ to form the protective shell. Upon proteolytic cleavage of the crosslinker, the polymeric shell disintegrated and the protein was released in functional form (58). This has proven to be effective by successful delivery of caspase-3 (CP-3), a peptidase in the apoptotic signaling pathway, through degradation of the cross-linked polymeric shell from within, promoting inhibition of proliferation and extensive apoptotic DNA fragmentation in cancer cell lines. Cancer cells treated with native CP-3 or NCs synthesized under identical conditions but with a nondegradable cross-linker did not show such characteristics (58).

For PDT, an increased photosensitizer affinity for tumor cells in order to reduce side effects on normal cells, as well as protection from thermal and photodegradation of the photosensitizer, are desired (59). Pietkiewicz et al. (60) reported polymeric oil-cored poly(n-butyl cyanoacrylate) (PBCA) NCs fabricated by means of o/w microemulsion templates formed by polyoxyethyleneted nonionics as promising nanocarriers for the delivery of hydrophobic cyanine-type photosensitizers. There was a discrepancy in size between the much bigger NCs and the corresponding microemulsion droplets, which probably resulted from the dynamic character of the microemulsion systems, assuming that the polymerization process did not involve a single droplet but several droplets at the same time. The preparation of NCs from the o/w microemulsion templates improved the encapsulation efficiency of cyanine IR-768, which was associated with the core rather than adsorbed on the surface, as shown by the sustained diameter and ZP, circumventing the undesirable characteristics of free cyanine.

Although PBCA NCs demonstrated low or moderate levels of hemolytic activity on human erythrocytes, it was concluded that intravenous injection of the NCs would result in lower serum concentrations compared to the in vitro experiments. Therefore, the NCs appeared to be relatively safe carriers of cyanine IR-768 in the circulation. The NCs were able to deliver cyanine IR-768 to cancer cell lines, and there was an initial burst release followed by a slow and sustained phase. The in vitro IR-768 leakage was dependent on the monomer concentration and not on the type of microemulsion. The dye did not aggregate inside the cells and could therefore act as an effective photosensitizer. Noteworthy, free-cyanine 
uptake caused significant changes in cell morphology while cells treated with IR-768-loaded NCs maintained a regular shape (60).

Shell cross-linked NCs were found to be efficient delivery vehicles for water-insoluble anti-cancer drugs such as PTX, and achieved effective cancer therapy by reducing the nonspecific side effects on normal tissue (61). The conventional PTX formulation induces acute side effects that are associated with the oil-based vehicle (62). PTX shows high affinity for, and strong binding to human serum albumin (HSA), and Lee et al. (61) employed HSA and amine-reactive multi-arm PEG to fabricate shell cross-linked NCs that incorporated PTX. Oil was not used and PTX was efficiently encapsulated into the hydrophobic interior by HSA-PTX interactions that were stabilized by a cross-linked shell layer consisting of PEG and HSA. As HSA is a negatively charged protein at neutral $\mathrm{pH}$, it is necessary to overcome the strong electrostatic repulsion hindering entry into cells through the negatively charged cell membrane. This was achieved by conjugation, using a flexible PEG linker, of the drugloaded NCs with the cell-penetrating peptide Hph1. Such modification enhanced the therapeutic performance of the loaded PTX against several cancer cell lines, and this could be induced by the Hph1-facilitated translocation of the NCs into the cells.

The biocompatible HSA/PEG PTX-NCs were structurally stable and the cytotoxic effect was attributed to PTXinduced apoptosis. In a mouse tumor model, clearance of the HSA/PEG NCs by the macrophages in the liver was minimal, suggesting that the NCs were targeted to and stayed in the tumor tissue for an extended period of time, with no severe nonspecific uptake by normal tissues. Tumor growth was significantly suppressed in mice that received a single iv dose of the NCs compared to untreated control mice (61).

Small interfering RNA (siRNA), a short double-stranded RNA less than 30 nucleotides in length, has received significant attention in biomedical research owing to its therapeutic potential. siRNAs function as effective mediators of post-transcriptional specific gene silencing via a mechanism called RNA interference (63). However, there are challenges in the application of siRNAs for anti-cancer therapy (64), as they exhibit poor in vivo stability by enzymatic degradation in the bloodstream. Lee et al. (65) developed pluronic/polyethylenimine (PEI) shell crosslinked NCs with embedded magnetite nanocrystals (PPMCs) for magnetically triggered intracellular delivery of siRNA. Pluronic is a biocompatible amphiphilic tri-block copolymer, and $\mathrm{PEI}$ is a cationic polymer used in non-viral gene delivery systems both in vitro and in vivo (66). However, its use to transfect tumors after systemic injection still represents an issue (67).

The formulation was produced by a modified emulsification/solvent evaporation procedure based on crosslinking at emulsion interfaces resulting in the formation of a pluronic/PEI composite shell layer encapsulating iron oxide nanocrystals in their hollow interior space. Since these NCs had a highly cationic shell layer they could be used as delivery vehicles for anionic therapeutic agents such as siRNA. The PPMCs were expected to interact electrostatically with the negatively charged siRNA-PEG conjugates to form nanosized polyelectrolyte complexes favorable for cell internalization. The application of an external magnetic field could direct the PPMC/siRNA-s-sPEG polyelectrolyte complexes into target cells. This enhances their uptake via endocytosis plus magnetically enforced cellular transport processes. The PPMCs suppressed gene expression in cancer cells, suggesting that they could be used as powerful nontoxic delivery vehicles for various nucleic acid-based therapeutic agents. In addition, the magnetic targeting of PPMCs greatly enhanced the efficiency of intracellular delivery and the gene silencing effect of the encapsulated siRNA (65).

The direct protein delivery to the cytosol in order to restore functions of interest is an interesting approach, but this has been hampered by some of the inherent characteristics of proteins. Therefore, vehicles for suitable protein delivery must meet certain criteria: they should protect the protein cargo from denaturation and proteolysis, shield the negatively charged protein, release the protein cargo in native forms when the desired destination is reached, not require covalent modification that can disturb protein folding and impair biological activity, and not exhibit low delivery efficiency or encounter difficulties due to colloidal instability (68-70). Zhao et al. (71) reported a method to encapsulate single protein molecules in a polymeric NC using a redox-responsible, disulfide-containing cross linker.

NCs interconnected by the cross-linker through interfacial polymerization should maintain the integrity of the thin polymer shell under the oxidative conditions outside the cell, but must be able to undergo rapid degradation and protein cargo release under the reducing conditions encountered upon entry into the cytosol. The formulation was internalized by the cells and a significant portion of the internalized NCs and the cargo escaped from the endosomal compartment and reached the desired destination. A human cancer cell line treated with CP-3 encapsulated in the NCs underwent extensive apoptotic DNA fragmentation, while apoptosis was not observed in cells treated with the negative control. This demonstrated that CP-3-NCs could be internalized by cancer cells, and that functional CP-3 was released into the cytosol where it induced apoptosis. The redox-responsive encapsulation strategy was a simple yet effective method of intracellular protein delivery (71).

\section{Liposome-like nanocapsules}

The concept of directly using drug molecules as components of NCs was demonstrated using the 
hydrophobic drug Camptothecin (CPT) (72). CPT was used to replace the fatty acid(s) in phospholipids, in a formulation that contained a short nonionic ethylene glycol chain as the water soluble part and a $\beta$-thioester bond as the linker. The formed liposome-like NCs acted as nanocarriers that released the CPT inside cells due to the presence of estearase. In addition, these liposomelike NCs could be efficiently loaded with DOX for combination therapy and showed high in vitro and in vivo antitumor activity.

The frequently used platinum-based drug cisplatin has problems related to cumulative toxicity. Liposomal formulations of cisplatin reduced toxicity but exhibited relatively low concentrations of platinum in tumor tissue (73). An alternative method using cisplatin NCs was evaluated against a panel of human ovarian carcinoma cell lines. The cisplatin NCs consisted of nanoprecipitates of cisplatin encapsulated in a phospholipid bilayer. The increased cytotoxicity caused by the cisplatin NCs was observed to be cell line-dependent (74). The in vitro cytotoxicity resulted from the uptake of the NCs by caveolae-mediated endocytosis. This led to increased intracellular accumulation of cisplatin and increased levels of platinum-DNA-adducts. In the absence of caveolin-1, the cisplatin NCs were taken up via clathrin-mediated endocytosis and became trapped in an endocytic compartment, resulting in a modest increase in platinum-DNAadduct formation and toxicity of the encapsulated versus the free drug. The observation that cytotoxicity depended on the route of cellular entry may have identified a new strategy for predicting the efficacy of nanoparticulate anticancer DDS against different types of tumors. The cisplatin NCs may be able to circumvent the blocking mechanisms used by platinum-resistant cells and destroy them (74).

\section{Protein nanocapsules}

Phosphorylation by protein kinases plays an important role in cell growth and functions through the activation of the target proteins via signal transduction pathways. Abnormal activation of certain protein kinases has been associated with many diseases (75). Casein kinase 2 (CK2) is a highly conserved and ubiquitous protein serine/threonine kinase with an important role in cancer. Besides being implicated in cell proliferation and differentiation, CK2 can also be a potent suppressor of apoptosis (76). Therefore, downregulation of CK2 is a potential cancer therapy strategy if it can be targeted to cancer cells. The inhibition of CK2 using NCs could enhance the tissue-specific targeting and therapeutic efficacy of this approach (77).

Protein kinase CK2 may interact with both NF-KB and TP53 pathways and thereby promote a malignant phenotype and its progression. NCs containing tenfibgen (the fibrinogen binding domain of tenascin) have been shown to enhance the intracellular delivery to tumor cells of the siRNA anti-CK $2 \alpha / \alpha^{\prime}$ oligodeoxynucleotide (ODN) that acts against both of the CK2 $\alpha$ and $\mathrm{CK} 2 \alpha^{\prime}$ subunits (78). The anti-CK2 $\alpha / \alpha^{\prime}$ ODN was encapsulated in sub$50-n m$ tenfibgen NCs and targeted CK2 $\alpha / \alpha^{\prime}$ in a head and neck squamous cell carcinoma xenograft model (77). Tumor growth was significantly suppressed and the expression of multiple proteins involved in NF- $\mathrm{B}$, TP53, and apoptotic pathways was altered. An additional therapeutic approach was developed to target protein kinase $C$ isozyme $(P K C \alpha)$ that is overexpressed or hyperactivated in cancer cells (79). This regulation system was provided by a PKC $\alpha$-specific substrate peptide that could distinguish between normal and tumor cells but was not tissue-specific.

BNCs are hollow nanoparticles that can be produced efficiently in recombinant yeast cells. They consist of hepatitis B virus (HBV) surface antigen molecules and a lipid bilayer. Intravenous injection of BNCs has allowed the efficient delivery of incorporated payloads to human hepatocytes by using the HBV infection machinery (80). The pre-S1 peptide displayed on the BNCs specifically recognizes human hepatocytes, and therefore provided, in combination with the tumor cell specific gene regulation, the desired selectivity for hepatoma cells.

Two conjugates were designed using N-methacryloylPEG (NPEG), the positive polymer NPEG(S) containing serine at the phosphorylation site of the peptide [peptide(S)], and the negative polymer NPEG(A) containing alanine [peptide(A)] that blocked phosphorylation by $P K C \alpha$. The NPEG(S) polymer was phosphorylated by $P K C \alpha$ after being incorporated into the polymer backbone and combined with DNA. The NPEG(S)-DNA complex was broken up by phosphorylation of the peptide and resulted in the release of the DNA from the complex. The delivery of the NPEG-DNA into cells was promoted by the BNCs. After transfection of the NPEG(S)-DNA-BNC complex, phosphorylation by PKC $\alpha$ induced gene expression. This complex increased transfection efficiency and resulted in cell-specific gene expression in hepatoma cells and tissues. No gene expression was observed in normal human hepatocytes or human epidermoid tumor cells, demonstrating that the system had hepatoma-specific gene expression both in vitro and in vivo (81).

A novel concept of immune-based therapy for lung cancer involved a vault NC for the delivery of immune potentiating cytokines. Vault NCs are naturally occurring ubiquitous cytoplasmic ribonucleoprotein particles, which may serve as a flexible therapeutic delivery vehicle. The effect of the vault NC delivery of CCL21, a lymphoid chemokine, on the growth of Lewis Lung (3LL) tumors in vivo was evaluated (82). The aim was to promote the recruitment of $\mathrm{T}$ lymphocytes and dendritic cells into the tumor microenvironment in order to stimulate a robust antitumor activity response. A single dose of the CCL21vault NCs induced potent antitumor activity and inhibited tumor growth. Neutralizing antibodies to CCL21 inhibited 
the chemotactic activity of the NCs, demonstrating that the antitumor activity was CCL21-dependent (82).

\section{Final remarks}

In the development of more effective and less harmful anticancer therapeutic agents, improved carrier systems are urgently needed. Carriers should be biocompatible, with the lowest possible cytotoxicity, and should not influence the therapeutic effect of the loaded bioactive substances. NCs, nanovesicular systems that can act as carriers of therapeutic molecules, have shown great potential in cancer research. They can enhance drug accumulation at a specific tumor site, thereby reducing the side effects associated with most chemotherapeutic drugs, and they can deliver DNA and siRNA. Most anticancer drugs have poor water solubility, rapid blood clearance, low tumor selectivity, and severe side effects for healthy tissues. Nanoencapsulated systems offer the appropriate physicochemical characteristics and modify the biodistribution of the encapsulated therapeutic agents. NCs can deliver higher payloads, shield the active molecules from degradation, prolong drug circulation time and delay their release. In addition, they can facilitate cellular uptake, improve drug targeting and solubility, and provide controlled release.

A further advantage is that more than one drug can be carried by the same nanoparticulate DDS, and they can be released in a sequential manner (56). Thus, the activity of a number of anticancer hydrophobic compounds can be improved (83). In addition, cellular uptake of the NCs by the endocytosis mechanism can be achieved (55). The self-degrading NC approach (58) may be useful in protein drugs or vaccines, and may be extended to applications in which external proteases trigger the disassembly of the NCs. Encapsulated radioactive components can allow imaging of the distribution of the targeted NCs for diagnostic and therapeutic uses (84). Antibodies can be attached to the NC surface, and antibody functionalized NCs can bind specifically to cancer cells expressing the complementary antigen (85).

LNCs can be coated by a post-insertion technique to improve their circulation times in order to give them the adequate features for in vivo injection and accumulation in tumors (26). Nevertheless, accessibility to ions decreases with PEG length, and since the conformation of PEG tends to be globular, the length of PEG should be adapted

\section{References}

1. Jain KK. Advances in the field of nanooncology. BMC Med 2010; 8: 83, doi: 10.1186/1741-7015-8-83.

2. Misra R, Acharya S, Sahoo SK. Cancer nanotechnology: application of nanotechnology in cancer therapy. Drug Discov Today 2010; 15: 842-850, doi: 10.1016/j.drudis.2010.08.006.

3. Bharali DJ, Mousa SA. Emerging nanomedicines for early for each application (28). For a delivery vehicle to be effective, it is desirable that it should not allow degradation of its content in the blood stream; however, it should easily release its cargo after reaching its destination within tumor cells (47). The size of nanodevices is also an important feature: if they are too large they will be removed from the bloodstream by the macrophages in the liver and spleen, whereas if they are too small they will be filtered by the kidneys. The ideal diameter of nanoparticles should be less than $200 \mathrm{~nm}$ for their efficient capture by the tumor vasculature (86), and NCs will be able to reach the targeted site through gaps in the endothelium (87).

LNC formulations are prepared using FDA-approved constituents in a solvent-free and low-energy process (18). Other formulation approaches also use biocompatible and biodegradable materials, with minimal, if any, cytotoxic effects, to construct a self-assembled core-shell NC (56). Besides, inorganic NCs can provide excellent cell uptake and high delivery efficiency of encapsulated drugs. Functional inorganic nanocrystals in the core of the NCs could allow simultaneous imaging and drug delivery functionalities (57). LbL assembly has proven to be advantageous (17), but alternatives have been proposed without multiple polymers and/or multiple polymer adsorption steps, such as template synthesis (88), providing NCs with thick shells. The nanoprecipitation technique can be used to encapsulate hydrophobic drugs into an amphiphilic copolymer, which can be self-assembled into a micellar structure in an aqueous environment (89). Another alternative is the use of natural functional macromolecular assemblies and structures that can be manipulated for nanobiotechnology applications. Protein engineering coupled with synthetic chemical strategies can be used to redesign structure and function, yielding biodegradable particles with very narrow size distributions and multifunctional control afforded by recombinant synthesis strategies (90).

In conclusion, the capability to generate a wide range of materials with tunable properties that can interact in a unique fashion with biological systems is providing exciting new opportunities for designing advanced NCs for use in a range of therapeutic and diagnostic applications. While several challenges remain to be addressed, undoubtedly NCs represent an interesting alternative for the development of new tools that can inhibit the growth of cancer cells. cancer detection and improved treatment: current perspective and future promise. Pharmacol Ther 2010; 128: 324335, doi: 10.1016/j.pharmthera.2010.07.007.

4. Lee PY, Wong KK. Nanomedicine: a new frontier in cancer therapeutics. Curr Drug Deliv 2011; 8: 245-253, doi: 10.2174/156720111795256110. 
5. Moghimi SM, Hunter AC, Murray JC. Long-circulating and target-specific nanoparticles: theory to practice. Pharmacol Rev 2001; 53: 283-318.

6. Vonarbourg A, Passirani C, Saulnier P, Benoit JP. Parameters influencing the stealthiness of colloidal drug delivery systems. Biomaterials 2006; 27: 4356-4373, doi: 10.1016/j.biomaterials.2006.03.039.

7. Maeda H, Wu J, Sawa T, Matsumura Y, Hori K. Tumor vascular permeability and the EPR effect in macromolecular therapeutics: a review. J Control Release 2000; 65: 271284, doi: 10.1016/S0168-3659(99)00248-5.

8. Wang M, Thanou M. Targeting nanoparticles to cancer. Pharmacol Res 2010; 62: 90-99, doi: 10.1016/j.phrs. 2010.03.005.

9. Luo J, Solimini NL, Elledge SJ. Principles of cancer therapy: oncogene and non-oncogene addiction. Cell 2009; 136: 823-837, doi: 10.1016/j.cell.2009.02.024.

10. Ji SR, Liu C, Zhang B, Yang F, Xu J, Long J, et al. Carbon nanotubes in cancer diagnosis and therapy. Biochim Biophys Acta 2010; 1806: 29-35.

11. Shapira A, Livney YD, Broxterman HJ, Assaraf YG. Nanomedicine for targeted cancer therapy: towards the overcoming of drug resistance. Drug Resist Updat 2011; 14: 150-163, doi: 10.1016/j.drup.2011.01.003.

12. Heath JR, Davis ME. Nanotechnology and cancer. Annu Rev Med 2008; 59: 251-265, doi: 10.1146/annurev.med. 59.061506.185523.

13. Mora-Huertas CE, Fessi H, Elaissari A. Polymer-based nanocapsules for drug delivery. Int J Pharm 2010; 385: 113142, doi: 10.1016/j.ijpharm.2009.10.018.

14. Ebrahimnejad $P$, Dinarvand $R$, Sajadi SA, Atyabi $F$, Ramezani $F$, Jaafari MR. Preparation and characterization of poly lactide-co-glycolide nanoparticles of SN-38. PDA J Pharm Sci Technol 2009; 63: 512-520.

15. Meier W. Polymer nanocapsules. Chem Soc Rev 2000; 29 : 295-303, doi: 10.1039/a809106d.

16. Johnston APR, Cortez C, Angelatos AS, Caruso F. Layerby-layer engineered capsules and their applications. Curr Opin Colloid Interface Sci 2006; 11: 203-209, doi: 10.1016/ j.cocis.2006.05.001.

17. Hirsjarvi S, Qiao Y, Royere A, Bibette J, Benoit JP. Layerby-layer surface modification of lipid nanocapsules. Eur $J$ Pharm Biopharm 2010; 76: 200-207, doi: 10.1016/j.ejpb. 2010.07.010.

18. Heurtault B, Saulnier P, Pech B, Proust JE, Benoit JP. A novel phase inversion-based process for the preparation of lipid nanocarriers. Pharm Res 2002; 19: 875-880, doi: 10.1023/A:1016121319668.

19. Heurtault B, Saulnier P, Pech B, Venier-Julienne MC, Proust JE, Phan-Tan-Luu R, et al. The influence of lipid nanocapsule composition on their size distribution. Eur J Pharm Sci 2003; 18: 55-61, doi: 10.1016/S0928-0987(02)00241-5.

20. Huynh NT, Passirani C, Saulnier P, Benoit JP. Lipid nanocapsules: a new platform for nanomedicine. Int J Pharm 2009; 379: 201-209, doi: 10.1016/j.jpharm.2009.04.026.

21. Manconi M, Mondini S, Fabiani A, Rossi P, Ambrosetto $P$, Cirignotta F. Anterior spinal artery syndrome complicated by the ondine curse. Arch Neurol 2003; 60: 1787-1790, doi: 10.1001/archneur.60.12.1787.

22. Vonarbourg A, Saulnier P, Passirani C, Benoit JP. Electrokinetic properties of noncharged lipid nanocapsules: influence of the dipolar distribution at the interface. Electrophoresis 2005; 26: 2066-2075, doi: 10.1002/ elps.200410145.

23. Lamprecht A, Benoit JP. Etoposide nanocarriers suppress glioma cell growth by intracellular drug delivery and simultaneous P-glycoprotein inhibition. J Control Release 2006; 112: 208-213, doi: 10.1016/j.jconrel.2006.02.014.

24. Roger E, Lagarce F, Benoit JP. The gastrointestinal stability of lipid nanocapsules. Int J Pharm 2009; 379: 260-265, doi: 10.1016/j.jpharm.2009.05.069.

25. Beduneau A, Saulnier P, Anton N, Hindre F, Passirani C, Rajerison $\mathrm{H}$, et al. Pegylated nanocapsules produced by an organic solvent-free method: Evaluation of their stealth properties. Pharm Res 2006; 23: 2190-2199, doi: 10.1007/ s11095-006-9061-y.

26. Morille M, Montier T, Legras P, Carmoy N, Brodin P, Pitard $B$, et al. Long-circulating DNA lipid nanocapsules as new vector for passive tumor targeting. Biomaterials 2010; 31: 321-329, doi: 10.1016/j.biomaterials.2009.09.044.

27. Huynh NT, Passirani C, Allard-Vannier E, Lemaire L, Roux $\mathrm{J}$, Garcion E, et al. Administration-dependent efficacy of ferrociphenol lipid nanocapsules for the treatment of intracranial 9L rat gliosarcoma. Int J Pharm 2012; 423: 5562, doi: 10.1016/j.jpharm.2011.04.037.

28. Perrier T, Saulnier P, Fouchet F, Lautram N, Benoit JP. Post-insertion into lipid nanocapsules (LNCs): From experimental aspects to mechanisms. Int J Pharm 2010; 396: 204209, doi: 10.1016/j.ijpharm.2010.06.019.

29. Tousignant JD, Gates AL, Ingram LA, Johnson CL, Nietupski $\mathrm{JB}$, Cheng $\mathrm{SH}$, et al. Comprehensive analysis of the acute toxicities induced by systemic administration of cationic lipid:plasmid DNA complexes in mice. Hum Gene Ther 2000; 11: 2493-2513, doi: 10.1089/10430340050207984.

30. Morille M, Passirani C, Letrou-Bonneval E, Benoit JP, Pitard B. Galactosylated DNA lipid nanocapsules for efficient hepatocyte targeting. Int J Pharm 2009; 379: 293-300, doi: 10.1016/j.ijpharm.2009.05.065.

31. Morille M, Passirani C, Dufort S, Bastiat G, Pitard B, Coll JL, et al. Tumor transfection after systemic injection of DNA lipid nanocapsules. Biomaterials 2011; 32: 2327-2333, doi: 10.1016/j.biomaterials.2010.11.063.

32. Bobo RH, Laske DW, Akbasak A, Morrison PF, Dedrick RL, Oldfield $\mathrm{EH}$. Convection-enhanced delivery of macromolecules in the brain. Proc Natl Acad Sci U S A 1994; 91: 20762080, doi: 10.1073/pnas.91.6.2076.

33. Hillard E, Vessieres A, Le Bideau F, Plazuk D, Spera D, Huche $\mathrm{M}$, et al. A series of unconjugated ferrocenyl phenols: prospects as anticancer agents. ChemMedChem 2006; 1 : 551-559, doi: 10.1002/cmdc.200500035.

34. Allard E, Passirani C, Garcion E, Pigeon P, Vessieres A, Jaouen $G$, et al. Lipid nanocapsules loaded with an organometallic tamoxifen derivative as a novel drug-carrier system for experimental malignant gliomas. $J$ Control Release 2008; 130: 146-153, doi: 10.1016/j.jconrel.2008.05.027.

35. Allard E, Jarnet D, Vessieres A, Vinchon-Petit S, Jaouen G, Benoit JP, et al. Local delivery of ferrociphenol lipid nanocapsules followed by external radiotherapy as a synergistic treatment against intracranial 9L glioma xenograft. Pharm Res 2010; 27: 56-64, doi: 10.1007/s11095-009-0006-0.

36. Roger M, Clavreul A, Huynh NT, Passirani C, Schiller P, Vessieres $A$, et al. Ferrociphenol lipid nanocapsule delivery 
by mesenchymal stromal cells in brain tumor therapy. Int $J$ Pharm 2012; 423: 63-68, doi: 10.1016/j.ijpharm.2011. 04.058.

37. Vanpouille-Box C, Lacoeuille F, Roux J, Aube C, Garcion E, Lepareur N, et al. Lipid nanocapsules loaded with rhenium-188 reduce tumor progression in a rat hepatocellular carcinoma model. PLoS One 2011; 6: e16926, doi: 10.1371/journal. pone.0016926.

38. Weyland M, Manero F, Paillard A, Gree D, Viault G, Jarnet $\mathrm{D}$, et al. Mitochondrial targeting by use of lipid nanocapsules loaded with SV30, an analogue of the small-molecule Bcl-2 inhibitor HA14-1. J Control Release 2011; 151: 74-82, doi: 10.1016/j.jconrel.2010.11.032.

39. Manero F, Gautier F, Gallenne T, Cauquil N, Gree D, Cartron PF, et al. The small organic compound HA14-1 prevents $\mathrm{Bcl}-2$ interaction with $\mathrm{Bax}$ to sensitize malignant glioma cells to induction of cell death. Cancer Res 2006; 66: 2757-2764, doi: 10.1158/0008-5472.CAN-05-2097.

40. Grée D, Vorin S, Manthati VL, Caijo F, Viault G, Manero F, et al. The synthesis of new, selected analogues of the proapoptotic and anticancer molecule HA 14-1. Tetrahedron Lett 2008; 49: 3276-3278, doi: 10.1016/j.tetlet.2008.03.070.

41. Lacoeuille F, Hindre F, Moal F, Roux J, Passirani C, Couturier $\mathrm{O}$, et al. In vivo evaluation of lipid nanocapsules as a promising colloidal carrier for paclitaxel. Int J Pharm 2007; 344: 143-149, doi: 10.1016/j.ijpharm.2007.06.014.

42. Hureaux J, Lagarce F, Gagnadoux F, Vecellio L, Clavreul A, Roger E, et al. Lipid nanocapsules: ready-to-use nanovectors for the aerosol delivery of paclitaxel. Eur J Pharm Biopharm 2009; 73: 239-246, doi: 10.1016/j.ejpb.2009.06.013.

43. Basile L, Passirani C, Huynh NT, Bejaud J, Benoit JP, Puglisi G, et al. Serum-stable, long-circulating paclitaxelloaded colloidal carriers decorated with a new amphiphilic PEG derivative. Int J Pharm 2012; 426: 231-238, doi: 10.1016/j.jpharm.2012.01.038.

44. Fukui Y, Fujimoto K. The preparation of sugar polymercoated nanocapsules by the layer-by-layer deposition on the liposome. Langmuir 2009; 25: 10020-10025, doi: 10.1021/ la9008834.

45. Tan JP, Wang Q, Tam KC. Control of burst release from nanogels via layer by layer assembly. J Control Release 2008; 128: 248-254, doi: 10.1016/j.jconrel.2008.03.012.

46. Yan Y, Such GK, Johnston AP, Lomas H, Caruso F. Toward therapeutic delivery with layer-by-layer engineered particles. ACS Nano 2011; 5: 4252-4257, doi: 10.1021/nn201793f.

47. Wang Y, Bansal V, Zelikin AN, Caruso F. Templated synthesis of single-component polymer capsules and their application in drug delivery. Nano Lett 2008; 8: 1741-1745, doi: $10.1021 / \mathrm{nl} 080877 \mathrm{c}$.

48. Quinn JF, Johnston AP, Such GK, Zelikin AN, Caruso F. Next generation, sequentially assembled ultrathin films: beyond electrostatics. Chem Soc Rev 2007; 36: 707-718, doi: 10.1039/b610778h.

49. Wang Y, Caruso F. Template synthesis of stimuli-responsive nanoporous polymer-based spheres via sequential assembly. Chem Mater 2006; 18: 4089-4100, doi: 10.1021/cm060866p.

50. Vergara D, Bellomo C, Zhang X, Vergaro V, Tinelli A, Lorusso $\mathrm{V}$, et al. Lapatinib/paclitaxel polyelectrolyte nanocapsules for overcoming multidrug resistance in ovarian cancer. Nanomedicine 2012; 8: 891-899, doi: 10.1016/ j.nano.2011.10.014.
51. Son KJ, Yoon HJ, Kim JH, Jang WD, Lee $Y$, Koh WG. Photosensitizing hollow nanocapsules for combination cancer therapy. Angew Chem Int Ed Engl 2011; 50: 11968-11971, doi: 10.1002/anie.201102658.

52. Huang Z, Xu H, Meyers AD, Musani Al, Wang L, Tagg R, et al. Photodynamic therapy for treatment of solid tumors potential and technical challenges. Technol Cancer Res Treat 2008; 7: 309-320.

53. Shojaei F, Ferrara N. Antiangiogenesis to treat cancer and intraocular neovascular disorders. Lab Invest 2007; 87: 227230, doi: 10.1038/labinvest.3700526.

54. Dorrell MI, Aguilar E, Scheppke L, Barnett FH, Friedlander M. Combination angiostatic therapy completely inhibits ocular and tumor angiogenesis. Proc Natl Acad Sci U S A 2007; 104: 967-972, doi: 10.1073/pnas.0607542104.

55. Wang Z, Ho PC. A nanocapsular combinatorial sequential drug delivery system for antiangiogenesis and anticancer activities. Biomaterials 2010; 31: 7115-7123, doi: 10.1016/ j.biomaterials.2010.05.075.

56. Wang Z, Ho PC. Self-assembled core-shell vasculartargeted nanocapsules for temporal antivasculature and anticancer activities. Small 2010; 6: 2576-2583, doi: 10.1002/smll.201001122.

57. Chen $\mathrm{Y}$, Chen H, Zeng D, Tian $\mathrm{Y}$, Chen F, Feng J, et al. Core/shell structured hollow mesoporous nanocapsules: a potential platform for simultaneous cell imaging and anticancer drug delivery. ACS Nano 2010; 4: 6001-6013, doi: $10.1021 / \mathrm{nn} 1015117$.

58. Gu Z, Yan M, Hu B, Joo KI, Biswas A, Huang Y, et al. Protein nanocapsule weaved with enzymatically degradable polymeric network. Nano Lett 2009; 9: 4533-4538, doi: 10.1021/nl902935b.

59. Bechet D, Couleaud P, Frochot C, Viriot ML, Guillemin F, Barberi-Heyob M. Nanoparticles as vehicles for delivery of photodynamic therapy agents. Trends Biotechnol 2008; 26: 612-621, doi: 10.1016/j.tibtech.2008.07.007.

60. Pietkiewicz J, Zielinska K, Saczko J, Kulbacka J, Majkowski M, Wilk KA. New approach to hydrophobic cyanine-type photosensitizer delivery using polymeric oil-cored nanocarriers: hemolytic activity, in vitro cytotoxicity and localization in cancer cells. Eur J Pharm Sci 2010; 39: 322-335, doi: 10.1016/j.ejps.2009.12.012.

61. Lee JY, Bae KH, Kim JS, Nam YS, Park TG. Intracellular delivery of paclitaxel using oil-free, shell cross-linked HSA multi-armed PEG nanocapsules. Biomaterials 2011; 32: 8635-8644, doi: 10.1016/j.biomaterials.2011.07.063

62. Gelderblom H, Verweij J, Nooter K, Sparreboom A Cremophor EL: the drawbacks and advantages of vehicle selection for drug formulation. Eur J Cancer 2001; 37: 15901598, doi: 10.1016/S0959-8049(01)00171-X.

63. Dykxhoorn DM, Palliser D, Lieberman J. The silent treatment: siRNAs as small molecule drugs. Gene Ther 2006; 13: 541-552, doi: 10.1038/sj.gt.3302703.

64. Oh YK, Park TG. siRNA delivery systems for cancer treatment. Adv Drug Deliv Rev 2009; 61: 850-862, doi: 10.1016/j.addr.2009.04.018.

65. Lee K, Bae KH, Lee Y, Lee SH, Ahn CH, Park TG. Pluronic/ polyethylenimine shell crosslinked nanocapsules with embedded magnetite nanocrystals for magnetically triggered delivery of siRNA. Macromol Biosci 2010; 10: 239-245, doi: 10.1002/mabi.200900291. 
66. Boussif $\mathrm{O}$, Lezoualc'h F, Zanta MA, Mergny MD, Scherman $D$, Demeneix $B$, et al. A versatile vector for gene and oligonucleotide transfer into cells in culture and in vivo: polyethylenimine. Proc Natl Acad Sci U S A 1995; 92: 72977301, doi: 10.1073/pnas.92.16.7297.

67. Chollet $P$, Favrot MC, Hurbin A, Coll JL. Side-effects of a systemic injection of linear polyethylenimine-DNA complexes. J Gene Med 2002; 4: 84-91, doi: 10.1002/jgm.237.

68. Lu Y, Yang J, Sega E. Issues related to targeted delivery of proteins and peptides. AAPS J 2006; 8: E466-E478, doi: 10.1208/aapsj080355.

69. Parveen S, Sahoo SK. Nanomedicine: clinical applications of polyethylene glycol conjugated proteins and drugs. Clin Pharmacokinet 2006; 45: 965-988, doi: 10.2165/00003088200645100-00002.

70. Ayame H, Morimoto N, Akiyoshi K. Self-assembled cationic nanogels for intracellular protein delivery. Bioconjug Chem 2008; 19: 882-890, doi: 10.1021/bc700422s.

71. Zhao M, Biswas A, Hu B, Joo KI, Wang P, Gu Z, et al. Redox-responsive nanocapsules for intracellular protein delivery. Biomaterials 2011; 32: 5223-5230, doi: 10.1016/ j.biomaterials.2011.03.060.

72. Shen Y, Jin E, Zhang B, Murphy CJ, Sui M, Zhao J, et al. Prodrugs forming high drug loading multifunctional nanocapsules for intracellular cancer drug delivery. J Am Chem Soc 2010; 132: 4259-4265, doi: 10.1021/ja909475m.

73. Terwogt JM, Groenewegen G, Pluim D, Maliepaard M, Tibben MM, Huisman A, et al. Phase I and pharmacokinetic study of SPI-77, a liposomal encapsulated dosage form of cisplatin. Cancer Chemother Pharmacol 2013; 49: 201-210, doi: $10.1007 / \mathrm{s} 002800100371$.

74. Hamelers IH, Staffhorst RW, Voortman J, de Kruijff B, Reedijk J, van Bergen en Henegouwen PM, et al. High cytotoxicity of cisplatin nanocapsules in ovarian carcinoma cells depends on uptake by caveolae-mediated endocytosis. Clin Cancer Res 2009; 15: 1259-1268, doi: 10.1158/ 1078-0432.CCR-08-1702.

75. Manning G, Whyte DB, Martinez R, Hunter T, Sudarsanam S. The protein kinase complement of the human genome. Science 2002; 298: 1912-1934, doi: 10.1126/science.1075762.

76. Trembley JH, Wang G, Unger G, Slaton J, Ahmed K. Protein kinase CK2 in health and disease: CK2: a key player in cancer biology. Cell Mol Life Sci 2009; 66: 1858-1867, doi: 10.1007/s00018-009-9154-y.

77. Brown MS, Diallo OT, Hu M, Ehsanian R, Yang X, Arun P, et al. CK2 modulation of NF-kappaB, TP53, and the malignant phenotype in head and neck cancer by antiCK2 oligonucleotides in vitro or in vivo via sub-50-nm nanocapsules. Clin Cancer Res 2010; 16: 2295-2307, doi: 10.1158/1078-0432.CCR-09-3200.

78. Wang G, Unger G, Ahmad KA, Slaton JW, Ahmed K.
Downregulation of CK2 induces apoptosis in cancer cells - a potential approach to cancer therapy. Mol Cell Biochem 2005; 274: 77-84, doi: 10.1007/s11010-005-3077-1.

79. Kang JH, Asai D, Kim JH, Mori T, Toita R, Tomiyama T, et al. Design of polymeric carriers for cancer-specific gene targeting: utilization of abnormal protein kinase Calpha activation in cancer cells. J Am Chem Soc 2008; 130: 14906-14907, doi: 10.1021/ja805364s.

80. Jung J, Matsuzaki T, Tatematsu K, Okajima T, Tanizawa K, Kuroda S. Bio-nanocapsule conjugated with liposomes for in vivo pinpoint delivery of various materials. $J$ Control Release 2008; 126: 255-264, doi: 10.1016/j.jconrel.2007.12.002.

81. Kang JH, Oishi J, Kim JH, ljuin M, Toita R, Jun B, et al. Hepatoma-targeted gene delivery using a tumor cell-specific gene regulation system combined with a human liver cellspecific bionanocapsule. Nanomedicine 2010; 6: 583-589, doi: 10.1016/j.nano.2010.01.007.

82. Kar UK, Srivastava MK, Andersson A, Baratelli F, Huang M, Kickhoefer VA, et al. Novel CCL21-vault nanocapsule intratumoral delivery inhibits lung cancer growth. PLOS One 2011; 6: e18758, doi: 10.1371/journal.pone.0018758.

83. Lacoeuille F, Garcion E, Benoit JP, Lamprecht A. Lipid nanocapsules for intracellular drug delivery of anticancer drugs. J Nanosci Nanotechnol 2007; 7: 4612-4617.

84. Ballot S, Noiret N, Hindre F, Denizot B, Garin E, Rajerison $\mathrm{H}$, et al. $99 \mathrm{mTc} / 188 \mathrm{Re}$-labelled lipid nanocapsules as promising radiotracers for imaging and therapy: formulation and biodistribution. Eur J Nucl Med Mol Imaging 2006; 33: 602-607, doi: 10.1007/s00259-005-0007-0.

85. Kamphuis MM, Johnston AP, Such GK, Dam HH, Evans RA, Scott AM, et al. Targeting of cancer cells using clickfunctionalized polymer capsules. J Am Chem Soc 2010; 132: 15881-15883, doi: 10.1021/ja106405c.

86. Sinn PL, Sauter SL, McCray PB Jr. Gene therapy progress and prospects: development of improved lentiviral and retroviral vectors - design, biosafety, and production. Gene Ther 2005; 12: 1089-1098, doi: 10.1038/sj.gt.3302570.

87. Gaumet M, Vargas A, Gurny R, Delie F. Nanoparticles for drug delivery: the need for precision in reporting particle size parameters. Eur J Pharm Biopharm 2008; 69: 1-9, doi: 10.1016/j.ejpb.2007.08.001.

88. Wang Y, Angelatos AS, Caruso F. Template synthesis of nanostructured materials via layer-by-layer assembly. Chem Mater 2008; 20.

89. Cheng J, Teply BA, Sherifi I, Sung J, Luther G, Gu FX, et al. Formulation of functionalized PLGA-PEG nanoparticles for in vivo targeted drug delivery. Biomaterials 2007; 28: 869876, doi: 10.1016/j.biomaterials.2006.09.047.

90. Ren D, Kratz F, Wang SW. Protein nanocapsules containing doxorubicin as a $\mathrm{pH}$-responsive delivery system. Small 2011; 7: 1051-1060, doi: 10.1002/smll.201002242. 